\title{
Comparative Study on Effects of Beetroot Juice and Dates in Iron Deficiency Anemia Patients
}

\author{
Sreekala Priyadharsini.K1' Brundha M.P2 and Leslie Rani. S 3 \\ ${ }^{1}$ Graduate student, Department of General Pathology, Saveetha Dental College, Saveetha \\ Institute of Medical and Technical sciences, Chennai, Tamil Nadu, India. \\ ${ }^{2}$ Associate professor, Department of General Pathology, Saveetha Dental College, Saveetha \\ Institute of Medical And Technical Sciences, Saveetha University. Chennai, Tamilnadu, India. \\ ${ }^{3}$ Tutor, Department of pathology, Saveetha Dental College and Hospitals, Saveetha Institute of \\ Medical and Technical Sciences, 162,Poonamallee High Road Chennai-600077 Tamil Nadu,India
}

\section{ABSTRACT}

Anaemia is a haematological disorder affecting most commonly the females. Though there are various haematinics available in market to increase the Red Blood Cell Count, it has some side effects also. The aim of this study is to evaluate the effects of natural substances like dates and beetroot juice on anaemia patients and to compare which has prominent and rapid effect in increasing all haematocrit values within a short duration of time. A total of 10 anemia patients were selected. They were divided into two groups. Sample A were given beetroot juice of $250 \mathrm{ml} .125 \mathrm{ml}$ in the midday and 125 in the evening(two times a day). Sample B were given 28 (250g) dates per day. 14 in the midday and 14 in the evening (two times a day) for other sets of patients. MCV, MCH, MCHC and $\mathrm{Hb} \%$ are recorded before and after consumption by sending blood samples to the medical lab of Saveetha dental college.There was a significant raise in $\mathrm{Hb}$ level and slight improvement or changes seen in MCV, $\mathrm{MCH}$ and MCHC in the patients who consumed Beetroot juice than the patients who consumed dates. Hence, we can conclude that both the beetroot juice and dates show invariably great effect in treating anaemia. But compared to dates, beetroot juice produces significant rise in Haemoglobin, MCV, $\mathrm{MCH}$ and MCHC.

\section{KEY WORDS: BEETROOT JUICE, ANEMIA, HAEMOGLOBIN, RED BLOOD CELL, DATES.}

\section{INTRODUCTION}

Anemia is a diminishing in the aggregate sum of red platelets or Hemoglobin in the blood or a brought capacity of the blood down to convey oxygen. (Peerschke, 2002). When anemia comes on slowly the symptoms

\section{ARTICLE INFORMATION}

*Corresponding Author: brundha.sdc@saveetha.com Received 1st August 2020 Accepted after revision 29th Sep 2020 Print ISSN: 0974-6455 Online ISSN: 2321-4007 CODEN: BBRCBA

Thomson Reuters ISI Web of Science Clarivate Analytics USA and Crossref Indexed Journal

\section{Clarivate
Analytics}

NAAS Journal Score 2020 (4.31) SJIF: 2020 (7.728)

A Society of Science and Nature Publication,

Bhopal India 2020. All rights reserved.

Online Contents Available at: http//www.bbrc.in/

Doi: http://dx.doi.org/10.21786/bbrc/13.8/114 are feeling tired, weakness,shortness of breath,and a poor ability to exercise (Janz and Hamilton, 2010). The diagnosis of anemia in men is based on a Hemoglobin less than $13 \mathrm{~g} / \mathrm{dl} 14 \mathrm{~g} / \mathrm{dL}$; in women it is between 12 to13 g/dL (Nissenson et al., 2005). Certain groups of individuals such as pregnant women benefit from the use of iron pills for treating anaemia (Bhutta et al., 2013). On assessment, the signs shown may incorporate whiteness yet this is certainly not a dependable sign.A bluish discolouration of the sclera may be noticed in some cases of iron deficiency anemia (Goodier, 2009). The most widely recognized reason for weakness is blood misfortune yet this typically doesn't cause any enduring side effects except if a generally hindered RBC creation creates, thus most normally by iron inadequacy. (Institute and National Cancer Institute, 2020). It is hard

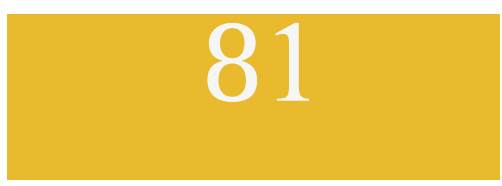


to quantify the RBC mass legitimately so the hematocrit or the Hemoglobin in the blood are regularly utilized rather to by implication gauge the worth (Uthman, 2009).Different elements liable for iron deficiency during pregnancy are gestational age, equality, continuous birth stretch, history of overabundance seeping during feminine cycle, intestinal parasitic contamination, jungle fever, interminable sickness and blood misfortune during pregnancy (Alemayehu et al., 2016).

The commonest reason for weakness is iron inadequacy, henceforth, it is regularly known as iron wholesome pallor (Fe). Sickliness influences around 33\% of the total populace, a large portion of the cases are brought about by iron lack, this is a significant general medical issue worldwide. Iron is a component required for the development of hemoglobin. At the point when feeble red platelets separate, iron is discharged, put away and reused. Iron is put away as Hemosiderin and ferritin. A lady needs around $15 \mathrm{mg}$ of iron to supplant the iron misfortune during feminine cycle. In instances of inordinate draining or ordinary seeping in feminine cycle, iron misfortune ought to be supplanted. In light of menstrual midpoints $60 \mathrm{ml}$ of blood for each month, which is equivalent to $30 \mathrm{mg}$ of iron, ladies need an additional milligram for every day to be ingested to look after parity. This shows how much ladies are getting influenced by pallor.

Beetroot is the taproot part of a beet plant (Eiger, 2009) typically referred to in North America as beet otherwise called table beet, garden beet, sugar beet, red beet, super beet or brilliant beet. It is one of a few developed assortments of Beta vulgaris developed for their edible taproots and leaves. At the point when beet juice is utilized, it is generally steady in nourishments with a low water content, for example, solidified oddities and natural product fillings (Francis, 1999). Late investigations give proof that Beetroot ingestion offers gainful physiology impacts that give clinical results to hypertension, atherosclerosis, type 2 diabetes and dementia (Ninfali and Angelino, 2013). Beetroot is a rich source of photochemical compound that includes ascorbic acid, carotenoids, phenolic acids and flavonoids. Beetroot is likewise one of only a handful not many vegetables that contain a gathering of exceptionally bioactive colors known as betalains.

(Lee et al., 2005). Nirman walker claimed that Beetroots build red corpuscles with betalain and add tone to blood by increasing Hemoglobin levels (Priya et al., 2013). The Beetroot being a basic food with $\mathrm{pH}$ from 7.5 to 8 has been acclaimed for its medical advantages, specifically for its infection battling cancer prevention agent potential, huge measure of nutrient $\mathrm{C}$ and nutrients B1, B2, niacin, B6, B12 while the leaves are an astounding wellspring of nutrient A (Zielinnska-Przyjemska et al., 2009).Betanin acquired from the roots is utilized mechanically as red food shading to improve the shading and kind of tomato glue, sauces, sweets, sticks and jams, frozen yogurt, candy and breakfast grains among different applications (Lock, Grubben and Denton, 2004).
Dates are fruits that contain iron which is enough to match the needs of iron, vitamin C, vitamin B complex and folic acid that can help the formation of red blood cells, so that by consuming the dates can help improve the formation of red blood cells and prevent anemia (Rahmani et al., 2014). Protein , carbohydrates and fats in dates support the synthesis of Hemoglobin (Sotolu, Kigbu and Oshinow, 2014). The combination of dates rich in glucose, Calcium, Iron, Zinc, Copper, Phosphorous, Niacin and content of vitaminA is able to improve Hemoglobin levels in anemic patients ('Assessment of yield and nutritional composition of fruit of wild date palm (Phoenix sylvestris Roxb.) cultivars', 2017). Dates are wealthy in selenium, manganese, copper and magnesium and these are required with regards to keeping our bones sound and forestalling osteoporosis. The potassium in dates assists with decreasing cholesterol and diminishes the danger of a stroke. Several studies were conducted showing intake of beetroot juice and dates increases the Haemoglobin level of anaemia patients. The aim of the study is to evaluate among Beetroot juice and Dates which has the better effects on iron deficiency anaemia patients.

\section{MATERIALS AND METHODS}

10 anemia patients were selected and divided into two groups Sample A and Sample B. Sample A group were given 28 dates (250g). 14 dates in the midday and 14 dates in the evening. Sample B groups were given Beetroot juice of $250 \mathrm{ml} .125 \mathrm{ml}$ in the mid day and 125 $\mathrm{ml}$ in the evening (two times a day). Both the groups were advised to continue the same for 21 days. The selected subjects were not suffering from any other chronic illness. Consent letter was signed by the participants and documented. MCV, MCH, MCHC and $\mathrm{Hb} \%$ of the subjects were recorded before and after consumption by sending blood samples to the medical lab of Saveetha Dental College.

Inclusion criteria: Patients with iron deficiency anaemia due to irregular menstruation.

Female patients with age groups between 15-30 years.

Exclusion criteria: Patients with diabetes, malignancy and other interminable illnesses. Patients under haematinics treatment. Patients under ayurvedic and homeopathic treatment.

\section{RESULTS AND DISCUSSION}

As iron deficiency anaemia is most prevalent among females, the participant chosen for this experimental study were females. The subjects of the study were between the age group of 15- 30 years of female. The process of iron deficiency takes several stages to become anaemia. If the iron deposits do not meet with iron intake, there will be significant reduction in haemoglobin concentration.

Group A, consumed Dates for 21 days. 
Table 1.1: Hb value in Anaemia Patients.

\begin{tabular}{|l|l|c|c|}
\hline & Mean & $\begin{array}{c}\text { Standard } \\
\text { deviation }\end{array}$ & SEM \\
\hline Before & 8.300 & 2.380 & 1.064 \\
\hline After & 8.500 & 2.380 & 1.064 \\
\hline $\begin{array}{l}\text { Student paired } \\
\text { T test p value }\end{array}$ & $<0.0001$ & \\
\hline
\end{tabular}

Table 1.2: MCV values in anemia patients.

\begin{tabular}{|l|c|c|c|}
\hline & Mean & $\begin{array}{c}\text { Standard } \\
\text { Deviation }\end{array}$ & SEM \\
\hline Before & 86.000 & 9.328 & 4.172 \\
\hline After & 86.760 & 8.812 & 3.941 \\
\hline $\begin{array}{l}\text { Student paired } \\
\text { T test p value }\end{array}$ & \multicolumn{3}{|c|}{$<0.05$} \\
\hline
\end{tabular}

Table 1.3: MCH Values in Anemia patients

\begin{tabular}{|l|c|c|c|}
\hline & Mean & $\begin{array}{c}\text { Standard } \\
\text { Deviation }\end{array}$ & SEM \\
\hline Before & 32.160 & 7.905 & 3.535 \\
\hline After & 33.220 & 7.826 & 3.500 \\
\hline $\begin{array}{l}\text { Student paired } \\
\text { T test p value }\end{array}$ & \multicolumn{3}{|c|}{$<0.0001$} \\
\hline
\end{tabular}

Table 1.4: MCHC values in anaemia patients.

\begin{tabular}{|l|c|c|c|}
\hline & Mean & $\begin{array}{c}\text { Standard } \\
\text { Deviation }\end{array}$ & SEM \\
\hline Before & 32.240 & 2.180 & 0.975 \\
\hline After & 33.440 & 2.503 & 1.119 \\
\hline $\begin{array}{l}\text { Student paired } \\
\text { T test p value }\end{array}$ & \multicolumn{3}{|c|}{$<0.0001$} \\
\hline
\end{tabular}

Their average value of Haemoglobin level (Table1.1), MCV (Table1.2), MCH(Table 1.3) and MCHC(Table1.4) were compared with before and after experiment by Student's t paired test value. From the tabulation it is clear that there is significant raise in all values of blood parameters after consumption of dates. The combination of dates rich in glucose, $\mathrm{Ca}, \mathrm{Fe}, \mathrm{Zn}, \mathrm{Cu}, \mathrm{P}$ and niacin content of vitamin $\mathrm{A}$ is able to improve hemoglobin levels in anemic patients.

Group B, had Beetroot juice for 21 days. Their average value of Haemoglobin level (Table2.1), MCV (Table 2.2),
MCH(Table 2.3) and MCHC(Table 2.4) were compared with before and after experiment by Student's t paired test value. From the tabulation it is clear that there is a significant raise in all values after consumption of Beetroot juice.

Table 2.1: Hb values in anaemia patients

\begin{tabular}{|l|c|c|c|}
\hline & Mean & $\begin{array}{c}\text { Standard } \\
\text { Deviation }\end{array}$ & SEM \\
\hline Before & 8.000 & 1.559 & 0.697 \\
\hline After & 8.440 & 1.483 & 0.663 \\
\hline $\begin{array}{l}\text { Student paired } \\
\text { T test p value }\end{array}$ & $<0.0001$ & \\
\hline
\end{tabular}

Table 2.2: MCV value in Anaemia patients

\begin{tabular}{|l|l|c|l|}
\hline & Mean & $\begin{array}{c}\text { Standard } \\
\text { Deviation }\end{array}$ & SEM \\
\hline Before & 24.440 & 5.899 & 2.638 \\
\hline After & 26.660 & 6.189 & 2.768 \\
\hline $\begin{array}{l}\text { Student paired } \\
\text { T test } p \text { value }\end{array}$ & $<0.0001$ & \\
\hline
\end{tabular}

Table 2.3: MCH value in Anaemia patients.

\begin{tabular}{|l|c|c|c|}
\hline & Mean & $\begin{array}{c}\text { Standard } \\
\text { Deviation }\end{array}$ & SEM \\
\hline Before & 74.880 & 15.006 & 6.711 \\
\hline After & 77.240 & 14.156 & 6.331 \\
\hline $\begin{array}{l}\text { Student paired } \\
\text { T test p value }\end{array}$ & $<0.05$ & \\
\hline
\end{tabular}

Table 2.3: MCH value in Anaemia patients.

\begin{tabular}{|l|c|c|c|}
\hline & Mean & $\begin{array}{c}\text { Standard } \\
\text { Deviation }\end{array}$ & SEM \\
\hline Before & 31.540 & 2.110 & 0.944 \\
\hline After & 33.080 & 2.406 & 1.076 \\
\hline $\begin{array}{l}\text { Student paired } \\
\text { T test p value }\end{array}$ & $<0.05$ & \\
\hline
\end{tabular}

This result supports previous studies reporting that beetroot is an excellent source of iron (Biondo et al., 2014). Beetroot (Beta vulgaris L.) is a main source of iron, nitrate, sodium, potassium, and betalain among vegetables. Easton Patrick (2011) states that consuming 
beetroot juice or cooked beet in salads is highly beneficial in treating anemia. The cost of beet root is also low as compared to other iron-rich vegetables and it is easy to store .

Figure 3.1: Comparison of Haemoglobin level between Dates and Beetroot juice

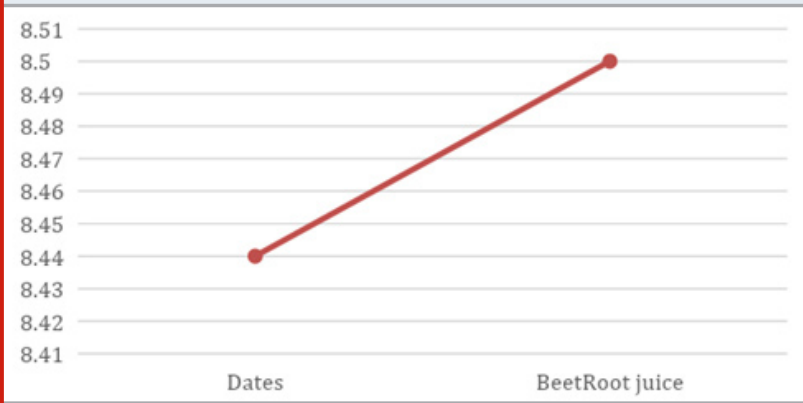

Figure 3.2: Comparison of MCV between Dates and Beetroot juice

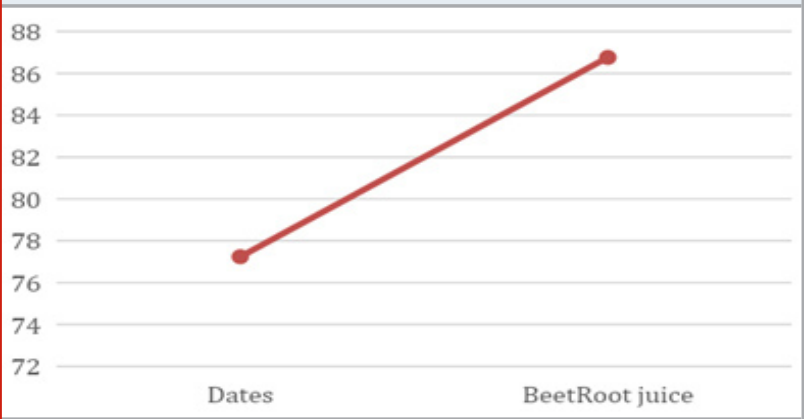

Figure 3.3: Comparison of $\mathrm{MCH}$ between Dates and Beetroot juice.

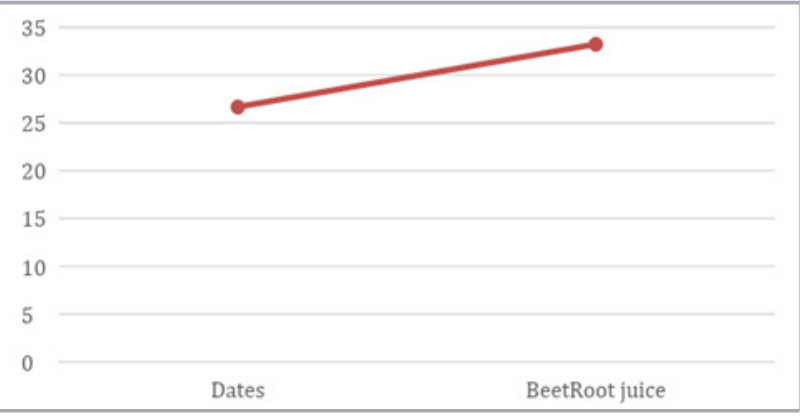

Figure 3.4: Comparison of MCHC between Dates and Beetroot juice

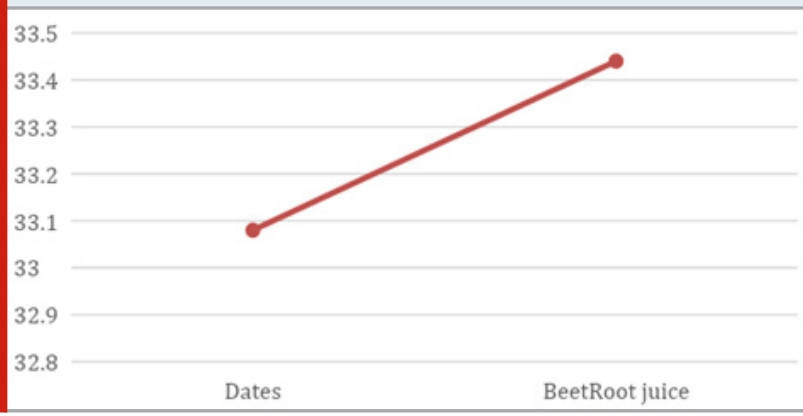

84
When compared between Group A and Group B, there was a significant raise in Hb level (Figure3.1) and slight improvement or changes were seen on MCV (Figure3.2), $\mathrm{MCH}$ (Figure3.3) and MCHC (Figure3.4) in patients who consumed Beetroot juice than the patients who consumed dates. It shows that both beetroot juice and dates can increase $\mathrm{Hb}$ level but beetroot juice increases the $\mathrm{Hb}$ level faster and more efficiently when compared to dates. If iron deposits have not been met with iron intake (Fe) there will be anemia symptoms accompanied by decreased hemoglobin. This study was a pilot study comprising only 10 subjects. Also, the duration of the study was just 3 weeks. It does not deal with other types of anaemia. As beetroot juice and date fruits are also good sources of vitamins, further research has to be done to analyse whether there is possibility in treating other forms of anaemia like pernicious and megaloblastic anaemia.

\section{CONCLUSION}

Based on the obtained data beetroot appears to be a powerful dietary source for several pathological disorders. Beetroot is one of the best ways to increase Hemoglobin levels. It is not only high in iron content but also folic acid along with potassium and fiber. Consuming both beetroot juice and dates increase the Hemoglobin in anemic patients but when compared to dates, beetroot juice increases the Hemoglobin more efficiently and rapidly. Therefore it is better to drink beetroot juice daily to ensure healthy blood count.

\section{ACKNOWLEDGEMENTS}

We thank Saveetha dental college for the support to carry out this study.

Conflict of Interest: None to declare

\section{REFERENCES}

Alemayehu, A. et al. (2016) 'Prevalence, Severity, and Determinant Factors of Anemia among Pregnant Women in South Sudanese Refugees, Pugnido, Western Ethiopia', Anemia, 2016, p. 9817358.

Assessment of yield and nutritional composition of fruit of wild date palm (Phoenix sylvestris Roxb.) cultivars' (2017) International Journal of Biosciences (IJB), pp. 85-91. doi: 10.12692/ijb/11.4.85-91.

Bhutta, Z. A. et al. (2013) 'Evidence-based interventions for improvement of maternal and child nutrition: what can be done and at what cost?', The Lancet, pp. 452-477. doi: 10.1016/s0140-6736(13)60996-4.

Biondo, P. B. F. et al. (2014) 'Evaluation of beetroot (Beta vulgaris L.) leaves during its developmental stages: a chemical composition study', Food Science and Technology, pp. 94-101. doi: 10.1590/s010120612014005000007.

Eiger, R. W. (2009) 'John Simpson (ed.): Oxford English Dictionary, Second Edition on CD-ROM Version 4.0', 
Publishing Research Quarterly, pp. 280-281. doi: 10.1007/s12109-009-9131-1.

Francis, F. J. (1999) 'Colorants'. doi: $10.1094 / 1891127004$.

Goodier, J. (2009) 'Lippincott Williams \& Wilkins Atlas of Anatomy200978Patrick W. Tank and Thomas R. Gest. Lippincott Williams \& Wilkins Atlas of Anatomy. Philadelphia, PA: Lippincott Williams \& Wilkins 2008. xV 432 pp., ISBN: 978078178505 1 £38 \$72.95', Reference Reviews, pp. 38-39. doi: 10.1108/09504120910935318.

Institute, N. C. and National Cancer Institute (2020) 'National Heart, Lung, and Blood Institute', Definitions. doi: 10.32388/afgalo.

Janz, T. G. and Hamilton, G. C. (2010) 'Anemia, Polycythemia, and White Blood Cell Disorders’, Rosen's Emergency Medicine - Concepts and Clinical Practice, pp. 1557-1577. doi: 10.1016/b978-0-323-05472$0.00119-5$.

Lee, C.-H. et al. (2005) 'Betalains, Phase II EnzymeInducing Components From Red Beetroot (Beta vulgaris L.) Extracts', Nutrition and Cancer, pp. 91-103. doi: 10.1207/s15327914nc5301_11.

Lock, M., Grubben, G. J. H. and Denton, O. A. (2004) 'Plant Resources of Tropical Africa 2. Vegetables', Kew Bulletin, p. 650. doi: 10.2307/4110929.

Ninfali, P. and Angelino, D. (2013) 'Nutritional and functional potential of Beta vulgaris cicla and rubra', Fitoterapia, pp. 188-199. doi: 10.1016/j. fitote.2013.06.004.

Nissenson, A. R. et al. (2005) 'Economic Burden of Anemia in an Insured Population', Journal of Managed Care Pharmacy, pp. 565-574. doi: 10.18553/ jmcp.2005.11.7.565.

Peerschke, E. I. B. (2002) 'Hematology: Clinical Principles and Applications, 2nd ed. Bernadette F. Rodak. Philadelphia, PA: WB Saunders Company, 2002, 852 pp., \$74.95, hardcover. ISBN 0-7216-8404-1', Clinical Chemistry, pp. 2299-2299. doi: 10.1093/ clinchem/48.12.2299.

Priya, N. G. et al. (2013) 'Beetroot juice on haemoglobin among adolescent girls', IOSR Journal of Nursing and Health Science, pp. 09-13. doi: 10.9790/19590210913.

Rahmani, A. H. et al. (2014) 'Therapeutic effects of date fruits (Phoenix dactylifera) in the prevention of diseases via modulation of anti-inflammatory, anti-oxidant and anti-tumour activity', International journal of clinical and experimental medicine. e-Century Publishing Corporation, 7(3), p. 483.

Sotolu, A. O., Kigbu, A. A. and Oshinow, A. J. (2014) 'Supplementation of Date Palm (Phoenix dactylifera) Seed as Feed Additive in the Diets of Juvenile African Catfish (Burchell, 1822)', Journal of Fisheries and Aquatic Science, pp. 359-365. doi: 10.3923/jfas.2014.359.365. Uthman, E. (2009) Understanding Anemia. Univ. Press of Mississippi.

Zielinnska-Przyjemska, M. et al. (2009) 'In vitroeffects of beetroot juice and chips on oxidative metabolism and apoptosis in neutrophils from obese individuals', Phytotherapy Research, pp. 49-55. doi: 10.1002/ ptr.2535. 